\title{
Cost Effectiveness of Sweet Potato Production Using Farmyard Manure and Inorganic Phosphorus Fertilizer at Assosa Western Ethiopia
}

\author{
Merga Boru \\ Ethiopian Institute of Agricultural Research/Assosa Agricultural Research Centre, Assosa, Ethiopia
}

Email address:

mergaboru23@gmail.com

\section{To cite this article:}

Merga Boru. Cost Effectiveness of Sweet Potato Production Using Farmyard Manure and Inorganic Phosphorus Fertilizer at Assosa Western Ethiopia. Journal of Plant Sciences. Vol. 7, No. 1, 2019, pp. 1-4. doi: 10.11648/j.plant.20190701.11

Received: May 22, 2019; Accepted: July 3, 2019; Published: July 13, 2019

\begin{abstract}
Sweet potato is one of the food security crop which has been cultivated in the South west, eastern and southern parts of Ethiopia over centuries. Despite that, the yield is below its genetic potential. This is due to less attention given to the crop in the region assuming that there is no response of the crop to fertilizers. A study was conducted to evaluate economic cost effectiveness of using farm yard manure and phosphorus fertilizer for sweet potato production in the study area. The treatment consisted of four levels of farm yard manure $\left(0,5,10\right.$ and $\left.15 \mathrm{t} \mathrm{ha}^{-1}\right)$ and four levels of $\mathrm{P}\left(0,23,46\right.$ and $69 \mathrm{~kg} \mathrm{P}_{2} \mathrm{O}_{5}$ ha $\left.{ }^{-1}\right)$. The experiment was laid out as a Randomized Complete Block Design in a factorial arrangement and replicated three times. Analysis of the result showed that using the rate of the combined fertilizers (15tha ${ }^{-1}$ farmyard manure and $69 \mathrm{~kg}^{\mathrm{k}} \mathrm{ha}^{-1}$ phosphorus) gave the highest yield (23.65tha-1) which gave the highest net benefit of 60033Birr ha ${ }^{-1}$. Therefore, if the farmers use by integrating $15 \mathrm{t} \mathrm{ha}^{-1}$ farm yard manure and $69 \mathrm{~kg} \mathrm{P}_{2} \mathrm{O}_{5} \mathrm{ha}^{-1}$, they can be more profitable in the study area.
\end{abstract}

Keywords: Farmyard Manure, Sweet Potato, Partial Budget, Phosphorus

\section{Introduction}

Sweet potato is a member of convolvulaceae family, genus Ipomia and species batatus [7]. It is accepted that the cultivated sweet potato has originated in Central America or tropical South America. It has large, starchy, sweet-tasting and tuberous roots. It adapts tropical and warm temperate regions. It is a highly heterozygous cross pollinated crop in which many of the traits show continuous variation. It does well in areas of high rainfall and it requires very little labor and care compared to other crops. Because it readily produces adventitious roots and has trailing vines, sweet potato can colonize soils easily. It is recognized as ideal crop for food security. The yellow and orange-fleshed sweet potato varieties are also known as a good source of vitamin A that is frequently lacking in diets of most African farming communities. However, most varieties in sub-Saharan Africa are white-fleshed, low yielding and lacking beta-carotene, the precursor of vitamin A that was found vital to pregnant women and children. Also, sweet potato is widely used as animal feed $[1,15]$
Sweet potato has been cultivated in Ethiopia for the last several years and over 95 percent of the crop is produced in the South west, eastern and southern parts, where it has remained for centuries as one of the major subsistence crops especially in the periods of drought [4]. In Ethiopia, low soil fertility is one of the factors limiting the productivity of different crops including sweet potato which may be caused due to removal of surface soil by erosion, nutrients removal of crop from the soil, complete removal of plant residue from farmland and lack of crop rotation system on the farm land $[2]$.

The national average yield of sweet potato which was estimated to $45.65 \mathrm{t} \mathrm{ha}^{-1}$, but the regional average yield of Benisangul Gumuz region was $15 \mathrm{t} \mathrm{ha}^{-1}$ which had $30 \mathrm{tha}^{-1}$ yield gap with the national average yield which implies lower productivity of the crop of the region due to less attention given to the crop in the region assuming that there is no response of the crop to fertilizers. [3]

Sweet potato producers in Ethiopia including Benishangul Gumuz, generally do not use inorganic fertilizer, because the response of various cultivars to fertilizers has not been 
clearly established, and because they assume that it is not cost-effective. Farmers do use organic fertilizer occasionally from farmyard manure on sweet potatoes and there is some evidence that using organic fertilizer in combination with phosphorus is effective in raising yields [8-12]. So, the objective of this study was to evaluate economic cost effectiveness of using farm yard manure and phosphorus fertilizer for sweet potato production in the study area

\section{Materials and Methods}

\subsection{Description of the Study Area}

The experiment was conducted under rain fed condition at research farm of Assosa Agricultural Research Center (ASARC) during 2016 cropping year from July to December. Assosa Agricultural Research Center is $660 \mathrm{~km}$ away from Addis Ababa which is located at latitude of $10^{\circ} 02^{\prime} \mathrm{N}$ and longitude of $34^{0} 34^{\prime} \mathrm{E}$ in western Ethiopia. The soil of the site was characteristically reddish brown (Nitosol), which is slightly acidic with $\mathrm{pH}$ of 5.7 and texturally clay.

\subsection{Treatments and Experimental Design}

The treatments consist of $4 \times 4$ factorial combinations of phosphorus $\left(0,23,46\right.$, and $\left.69 \mathrm{~kg} \mathrm{P}_{2} \mathrm{O}_{5} \mathrm{ha}^{-1}\right)$ and FYM $(0,5,10$, $\left.15 \mathrm{ha}^{-1}\right)$. The treatments were arranged in a randomized complete block design (RCBD) with three replications. A sweet potato variety Awassa 83, was used for the experiment. Triple super TSP containing $46 \% \mathrm{P}_{2} \mathrm{O}_{5}$ was used as inorganic fertilizer sources and well decomposed farmyard manure (FYM) on dry weight basis was used as source of organic fertilizer.

\subsection{Data Collection}

Data were collected on parameters like total tuber yield, and marketable tuber yield. All data were subjected to analysis of variance using SAS 9.2software. For treatments that were significant, mean separation was done using the Least Significant Difference (LSD) test at 5\% probability level.

\subsection{Partial Budget Analysis}

Partial budget analysis was employed for economic analysis of fertilizer application and it was carried out for tuber yield. The potential response of crop towards the added fertilizer and price of fertilizers during planting ultimately determine the economic feasibility of fertilizer application (CIMMYT, 1988). To estimate economic parameters, sweet potato tuber was valued at an average open market price of 4.00 birr $\mathrm{kg}^{-1}$. To estimate the total costs, mean current prices of TSP (23 Birr $\mathrm{kg}^{-1}$ ), and manure (1500 birr $\mathrm{t}^{-1}$ ) were considered at the time of planting.

Twenty workers for manure application, sixteen workers for phosphorus application were considered per hectare. The wage rate per worker was 30 Birr per day. Cost of protection, storage, planting material, post harvest, and others were not included in the calculation. The economic analysis was based on the formula developed by CIMMYT (1988) and given as follows:
Marketable tuber yield (ton $\mathrm{ha}^{-1}$ ): is an average yield of each treatment

Adjusted yield (AJY): is the average yield adjusted downward by a $10 \%$ to reflect the difference between the experimental yield and yield of farmers.

$$
\mathrm{AJY}=\mathrm{MTY}-(\mathrm{GAY} * 0.1)
$$

Gross field benefit (GFB): was computed by multiplying field/farm gate price that farmers receive for the crop when they sale it by adjusted yield.

$$
\mathrm{GFB}=\mathrm{AJY} * \text { field/farm gate price of a crop }
$$

Total variable cost (TVC): mean current cost of FYM (150 birr /100 kg), TSP (23 birr $\mathrm{kg}^{-1}$ ), wage for manure application, and phosphorusapplication, were considered per hectare.

Net benefit (NB): was calculated by subtracting the total variable costs from the gross field benefit for each treatment.

$$
\mathrm{NB}=\mathrm{GFB}-\mathrm{TVC}
$$

Marginal Benefit $(\mathrm{MB})=$ Change in benefit between treatments

Marginal cost $(\mathrm{MC})=$ Change in cost between treatments Marginal rate of return $(\mathrm{MRR}(\%)=(\mathrm{MB} / \mathrm{MC}) * 100$

\section{Result and Discussion}

Total tuber yield of sweet potato was significantly affected by the interaction of farmyard manure and phosphorus. The maximum tuber yield per hectare $\left(24.6 \mathrm{t} \mathrm{ha}^{-1}\right)$ was recorded at $15 \mathrm{t} \mathrm{FYM} \mathrm{ha}^{-1}+69 \mathrm{~kg} \mathrm{P}_{2} \mathrm{O}_{5} \mathrm{ha}^{-1}$ and the lowest yield $(5.5 \mathrm{t}$ $\mathrm{ha}^{-1}$ ) was recorded at $0 \mathrm{t} \mathrm{FYM} \mathrm{ha}^{-1}+0 \mathrm{~kg} \mathrm{P}_{2} \mathrm{O}_{5} \mathrm{ha}^{-1}$.

The large yield gap between the treatments may be due to the low fertility level of the experimental site which resulted lowest yield but when it was amended with FYM in combination with $\mathrm{P}$, the soil became productive and reach and enabled to give better yield. This result agrees with the findings of [5] where they have observed that the nutrient use efficiency of a crop increased through a combined application of organic manure and inorganic fertilizer. In addition, the combination of $15 \mathrm{t} \mathrm{FYM} \mathrm{ha}^{-1}+69 \mathrm{~kg} \mathrm{P}_{2} \mathrm{O}_{5} \mathrm{ha}^{-1}$ produced the highest marketable root yield $\left(23.65 \mathrm{t} \mathrm{ha}^{-1}\right)$ while the lowest yield $\left(5.6 \mathrm{tha}^{-1}\right)$ was from $0 \mathrm{t} \mathrm{ha}^{-1} \mathrm{FYM}+0$ $\mathrm{kg} \mathrm{P}_{2} \mathrm{O}_{5} \mathrm{ha}^{-1}$

Table 1. Effect of applied FYM and Phosphorus fertilizer on marketable tuberousroot yield ( $t \mathrm{ha}^{-1}$ ) of sweet potato in 2016 cropping season.

\begin{tabular}{lllll}
\hline Treatments & \multicolumn{4}{l}{$\mathbf{P}_{2} \mathbf{O}_{5}$ rate $\left(\mathbf{k g ~ h a}^{-1}\right)$} \\
\hline FYM $\left(\mathrm{t} \mathrm{ha}^{-1}\right)$ & 0 & 23 & 46 & 69 \\
0 & $3.61^{\text {gh }}$ & $5.02^{\text {h }}$ & $5.88^{\text {efgh }}$ & $5.42^{\text {fgh }}$ \\
5 & $9.13^{\text {bcdefg }}$ & $4.85^{\text {fgh }}$ & $5.88^{\text {efgh }}$ & $4.60^{\text {gh }}$ \\
10 & $6.85^{\text {defgh }}$ & $8.78^{\text {cdefg }}$ & $9.55^{\text {bcdef }}$ & $11.98^{\text {bc }}$ \\
15 & $10.76^{\text {bcde }}$ & $11.10^{\text {bcd }}$ & $13.735^{\text {b }}$ & $23.65^{\text {a }}$ \\
LSD (PxFYM) & & 4.91 & & \\
CV $(\%)$ & 34 & & \\
\hline
\end{tabular}

$\mathrm{CV}$ : Coefficient of variations; LSD: least significance difference: means sharing common letter(s) are not significantly different at 5\% level of significance. 


\section{Partial Budget Analysis of Fym and Phosphorus Application}

The highest tuber yield $\left(23.65 \mathrm{t} \mathrm{ha}^{-1}\right)$ was recorded at $15 \mathrm{t}$ FYM ha ${ }^{-1}+69 \mathrm{~kg} \mathrm{P}_{2} \mathrm{O}_{5} \mathrm{ha}^{-1}$. Similarly, the adjusted tuber yield (23.65 $\mathrm{t} \mathrm{ha}^{-1}$ ) according to CIMMYT (1988) was high when $15 \mathrm{t} \mathrm{FYM} \mathrm{ha}^{-1}+69 \mathrm{P}_{2} \mathrm{O}_{5} \mathrm{~kg} \mathrm{ha}^{-1}$ was applied (Table 2).

The partial budget analysis indicated that the highest net benefit of 60,033 Birr ha ${ }^{-1}$ was recorded at $15 \mathrm{t} \mathrm{FYM} \mathrm{ha}^{-1}+$ $69 \mathrm{~kg} \mathrm{P}_{2} \mathrm{O}_{5} \mathrm{ha}^{-1}$ (Table 2). From the above results, it was apparent that the treatments with $15 \mathrm{t} \mathrm{FYM} \mathrm{ha}^{-1}+69 \mathrm{~kg} \mathrm{P}_{2} \mathrm{O}_{5}$ $\mathrm{ha}^{-1}$ were more profitable and cost effective than other treatment combinations.

Marginal rate of tuber analysis was performed on non- dominated treatments to identify treatments with the optimum return to the farmers' investment. In order to consider a treatment as worthwhile option to farmers, $100 \%$ marginal rate of return (MRR) is minimum acceptable rate of return (CIMMYT, 1988). MRR at $15 \mathrm{t} \mathrm{FYM} \mathrm{ha}^{-1}+69 \mathrm{~kg}$ $\mathrm{P}_{2} \mathrm{O}_{5} \mathrm{ha}^{-1}$ gave a value that was higher $(6667.5 \%)$ indicating that $15 \mathrm{t} \mathrm{FYM} \mathrm{ha}^{-1}+69 \mathrm{~kg} \mathrm{P}_{2} \mathrm{O}_{5} \mathrm{ha}^{-1}$ used in this study was the economic optimum rate for the crop.

Therefore, application of farmyard manure in combination with Phosphorus fertilizer is economically profitable for the farmers in Assosa and areas with similar agro ecology if they use the rate recommended above with good crop management and can easily rise up their income.

Table 2. Partial budget analysis of FYM $\left(\right.$ ton $\left.\mathrm{ha}^{-1}\right)$ and $P\left(\mathrm{~kg} \mathrm{ha}^{-1}\right)$ applied at different rate of combinations.

\begin{tabular}{|c|c|c|c|c|c|c|c|}
\hline \multicolumn{2}{|l|}{ TRT } & \multirow{2}{*}{$\operatorname{MTY}\left(\mathrm{t} \mathrm{ha}^{-1}\right)$} & \multirow{2}{*}{$\operatorname{ATY}\left(\mathbf{t ~ h a}^{-1}\right)$} & \multirow{2}{*}{ GFB (Birr ha-1) } & \multirow{2}{*}{ TVC (Birr ha-1) } & \multirow{2}{*}{ NB (Birr ha $\left.{ }^{-1}\right)$} & \multirow{2}{*}{ MRR (\%) } \\
\hline FYM $\left(\mathrm{t} \mathrm{ha}^{-1}\right)$ & $\mathrm{P}_{2} \mathrm{O}_{5}\left(\mathrm{~kg} \mathrm{ha}^{-1}\right)$ & & & & & & \\
\hline 0 & 0 & 3.6 & 3.24 & 12960 & 0 & 12960 & - \\
\hline 0 & 23 & 5.02 & 4.52 & 18080 & 1009 & 17071 & \\
\hline 0 & 46 & 5.885 & 5.3 & 21200 & 1538 & 19662 & 480 \\
\hline 0 & 69 & 5.42 & 4.88 & 19520 & 2067 & 17453 & - \\
\hline 5 & 0 & 9.125 & 8.2 & 32800 & 8100 & 24700 & 120 \\
\hline 5 & 23 & 4.85 & 4.4 & 17600 & 9109 & 8691 & - \\
\hline 5 & 69 & 4.6 & 4.14 & 16560 & 10189 & 6371 & - \\
\hline 10 & 0 & 6.85 & 6.2 & 24800 & 15600 & 9200 & 52 \\
\hline 10 & 23 & 8.78 & 7.9 & 31600 & 16609 & 14991 & 574 \\
\hline 10 & 46 & 9.55 & 8.6 & 34400 & 17138 & 17262 & 430 \\
\hline 10 & 69 & 11.98 & 10.8 & 43200 & 19227 & 23973 & 772.2 \\
\hline 15 & 0 & 10.76 & 9.7 & 38800 & 23100 & 14500 & - \\
\hline 15 & 23 & 11.1 & 9.99 & 39960 & 24109 & 14651 & 150 \\
\hline
\end{tabular}

$\mathrm{TRT}=$ treatment, $\mathrm{FYM}=$ Farmyard manure, $\mathrm{MTY}=$ Marketable tuber yield, $\mathrm{AJY}=$ Adjusted marketable tuber yield, GFB=Gross field benefit, $\mathrm{TVC}=\mathrm{Total}$ variable cost, $\mathrm{NB}=$ Net benefit, $\mathrm{MRR}=$ Marginal rate of return.

\section{Summary and Conclusion}

It can be summarized that by using farmyard manure and phosphorus fertilizer, the highest tuber yield $\left(23.65 \mathrm{t} \mathrm{ha}^{-1}\right)$ was recorded at $15 \mathrm{t} \mathrm{FYM} \mathrm{ha}^{-1}+69 \mathrm{~kg} \mathrm{P}_{2} \mathrm{O}_{5} \mathrm{ha}^{-1}$. The partial budget analysis indicated that the highest net benefit of $60,033 \mathrm{Birr} \mathrm{ha}^{-1}$ was recorded at $15 \mathrm{t} \mathrm{FYM} \mathrm{ha}^{-1}+69 \mathrm{~kg} \mathrm{P}_{2} \mathrm{O}_{5}$ $\mathrm{ha}^{-1}$ and the (MRR) according to [16] indicated that using the above rate of fertilizer gave $(6667.5 \%)$ meaning that using the combination of the two fertilizers can make the farmers of the study areas more profitable and enables them to boost up their income by producing sweet potato.

Therefore, it is highly recommendable that using fertilizers is cost effective for the farmers of the study areas rather than producing without fertilizer.

\section{References}

[1] Assefa, A. Teshome, T. Engida, and T. Tesfaye, "Summary of progress on orange-fleshed sweetpotato research and development in Ethiopia," in Proceedings of the 13th ISTRC Symposium, 2007, pp. 728-731.
[2] Chung RS, Wang CH, Wang CW, Wang YP. 2000. Influence of organic matter and inorganic fertilizer on the growth and nitrogen accumulation of corn plants. Journal of Plant Nutrition 23 (3): 297-311.

[3] CSA (Central Statistical Agency). 2016. Ethiopian Agricultural Sample Enumeration, 2016. Report on area and production of major crops, Volume I, Addis Ababa, Ethiopia.

[4] Endale, Taboge, Geleta, L, Mulugeta, D. And Terefe, B. 1992. Improvement Studies on Ensete and Sweet Potato. Pp. 63-74. In: Horticultural Research and Development in Ethiopia. Proc second. Natl. Hort. Workshop of Ethiopia, 13 Dec., 1992. Addis Ababa, Ethiopia.

[5] Murwira HK, Kirchman H. 1993. Carbon and nitrogen mineralization of cattle manures subjected to different treatments in Zimbabwean and Swedish soils. In: R. Merrkx and J. Mulongoy (Eds.) The dynamics of soil organic matter in relation to the sustainability of tropical agriculture, John Wiley $\&$ Sons. Leuven, Belgium.

[6] Onwueme, I. C. and Sinha, T. O. 1991. "Field crop production in Tropical Africa, principles and practice". CTA (Technical Centre for Agriculture and Rural Cooperation), Ede. The Netherlands. pp. 267-275. 
[7] Purseglove, J. W. 1972. Tropical crops: Dicotyledons. Landon, longman.

[8] Reijntjes, Coen. Haurkort, Bertus and Ann Waters Bayer, 1992. Farming For Future: An Introduction to Low-External Input and sustainable Agriculture. The Macmillan Press Ltd. London.

[9] Yeng, S. B., Agyarko, K., Dapaah, H. K, Adomako, W. J. and Asare, E. 2012. Growth and yield of sweet potato (Ipomoea batatas L.) as influenced by integrated application of chicken manure and inorganic fertilizer. African Journal of Agricultural Research, 7 (39): 5387-5395.

[10] Teshome Abdissa, Nigussie Dechassa and Yibekal Alemayehu. 2012. Sweet Potato Growth Parameters as Affected by Farmyard Manure and Phosphorus Application at Adami Tulu, Central Rift Valley of Ethiopia. Agricultural Science Research Journal, 2 (1), pp. 1-12.

[11] Tesfaye Balemi. 2012. Effect of integrated use of cattle manure and inorganic fertilizers on tuber yield of potato in Ethiopia; Journal of Soil Science and Plant Nutrition, 12 (2), 253-261.
[12] Deshmukh, S. S., Chaudhari V. S., Narkhede, S. D., Jadhav, R. N. and Attarde, S. B. 2010. Effects of three different composts on the growth rate of wheat. International Journal of Plant Sciences, 6 (1): 22-26.

[13] Cheng-Wei, L. A., Sung, Y., Bo-Ching C. and Hung-Yu, L. 2014: Effects of nitrogen fertilizers on the growth and nitrate content of lettuce (Lactuca sativa L.); sInternational Journal ofEnvironmental Research Public Health; 11 (4): 4427-4440.

[14] Terefe Belehu 2003. Agronomical and physiological factors affecting growth, development and yield of sweet potato in Ethiopia. Doctoral dissertation, University of Pretoria.

[15] Manal, A. B. D., Hameed, E. L., Mandour. 2011. Growth and productivity of some sweet potato cultivars as affected by some vitamins, salicylic acid and plant density under sandy soil conditions. M.Sc. Agric. (Horticulture-Vegetables), Fac. Agric., Zagazig University Abstract part.

[16] CIMMYT 1988. From agronomic data to farmer recommendations. An economics training manual. Completely revised edition. D. F, Mexico 51p. 